education and training in the fields of diplomacy, human rights law, democratic processes, conflict resolution and environmental protection. Members, private foundations and voluntary contributions fund the Organization.

In total six former members of UNPO (Armenia, Belau, East Timor, Estonia, Georgia and Latvia) subsequently achieved full independence and gained representation in the UN. Belau is now called Palau. Current members Bougainville and Kosovo are progressively achieving self-determination.

Headquarters: 40A Javastraat, NL-2585 AP The Hague,

Netherlands.

Website: http://www.unpo.org

General Secretary: Marino Busdachin.

Publication. UNPO News (quarterly).

\section{World Confederation of Labour (WCL)}

Founded in 1920 as the International Federation of Christian Trade Unions, it went out of existence in 1940 as a large proportion of its $3.4 \mathrm{~m}$. members were in Italy and Germany, where affiliated unions were suppressed by the Fascist and Nazi regimes. Reconstituted in 1945 and declining to merge with the WFTU or ICFTU, its policy was based on the papal encyclicals Rerum novarum (1891) and Quadragesimo anno (1931), and in 1968 it became the WCL and dropped its openly confessional approach.

Today, it has Christian, Buddhist and Muslim member confederations, as well as organizations without religious reference. The WCL defines itself as pluralist and humanist. In its concern to defend trade union freedoms and assist trade union development, the WCL differs little in policy from the ICFTU (see pages $50-1$ ). A membership of $26 \mathrm{~m}$. in 116 countries is claimed. The biggest group is the Confederation of Christian Trade Unions (CSC) of Belgium (1.6m.).

Organization. The WCL is organized on a federative basis which leaves wide discretion to its autonomous constituent unions. Its governing body is the Congress, which meets every four years. The Congress appoints (or re-appoints) the SecretaryGeneral at each four-yearly meeting. The General Council, which meets at least once a year, is composed of the members of the Confederal Board (at least 22 members, elected by the Congress) and representatives of national confederations, international trade federations, and trade union organizations where there is no confederation affiliated to the WCL. The Confederal Board is responsible for the general leadership of the WCL, in accordance with the decisions and directives of the Council and Congress. There are regional organizations in Latin America (Caracas), Africa (Lomé) and Asia (Manila), and three liaison offices (Bucharest, Geneva and Washington).

Headquarters: 33 rue de Trèves, Brussels 1040, Belgium.

Website: http://www.cmt-wcl.org

Secretary-General: Willy Thys (Belgium).

President: Basile Mahan Gahé (Côte d'Ivoire).

Publications. Annual Report on Workers Rights; Teleflash (20 a year); Labor Magazine (4 a year).

\section{World Council of Churches}

The World Council of Churches was formally constituted on 23 Aug. 1948 in Amsterdam. Today, member churches number over 340 from more than 120 countries.

Origin. The World Council was founded by the coming together of Christian movements, including the overseas mission groups gathered from 1921 in the International Missionary Council, the Faith and Order Movement, and the Life and Work Movement. On 13 May 1938, at Utrecht, a provisional committee was appointed to prepare for the formation of a World Council of Churches.

Membership. The basis of membership (1975) states: 'The World Council of Churches is a fellowship of Churches which confess the Lord Jesus Christ as God and Saviour according to the Scriptures and therefore seek to fulfil together their common calling to the glory of the one God, Father, Son and Holy Spirit.' Membership is open to Churches which express their agreement with this basis and satisfy such criteria as the Assembly or Central Committee may prescribe. Today, more than 340 Churches of Protestant, Anglican, Orthodox, Old Catholic and Pentecostal confessions belong to this fellowship.

Activities. The WCC's Central Committee comprises the Programme Committee and the Finance Committee. Within the Programme Committee there are advisory groups on issues relating to communication, women, justice, peace and creation, youth, ecumenical relations and inter-religious relations. Following the WCC's 8th General Assembly in Harare, Zimbabwe in 1998 the work of the WCC was restructured. Activities were grouped into four 'clusters'-Relationships; Issues and Themes; Communication; and Finance, Services and Administration. The Relationships cluster comprises four teams (Church and Ecumenical Relations, Regional Relations and Ecumenical Sharing, InterReligious Relations and International Relations), as well as two programmes (Action by Churches Together and the Ecumenical Church Loan Fund). The Issues and Themes cluster comprises four teams (Faith and Order; Mission and Evangelism; Justice, Peace and Creation; and Education and Ecumenical Formation).

In Aug. 1997 the WCC launched a Peace to the City campaign, as the initial focus of a programme to overcome violence in troubled cities. The Decade to Overcome Violence was launched in Feb. 2001 during the meeting of the WCC Central Committee in Berlin.

Organization. The governing body of the World Council, consisting of delegates specially appointed by the member Churches, is the Assembly, which meets every seven or eight years to frame policy. It has no legislative powers and depends for the implementation of its decisions upon the action of member Churches. The 9th General Assembly, held in Porto Alegre, Brazil in Feb. 2006, had as its theme 'God, in your grace, transform the world'. A 154-member Central Committee meets annually to carry out the Assembly mandate, with a smaller 25-member Executive Committee meeting twice a year.

Headquarters: PO Box 2100, 150 route de Ferney, 1211

Geneva 2, Switzerland.

Website: http://www.wcc-coe.org

General Secretary: Rev. Dr Samuel Kobia (Kenya).

Publications. Annual Reports; Dictionary of the Ecumenical Movement, Geneva, 1991; Directory of Christian Councils, 1985; A History of the Ecumenical Movement, Geneva, 1993; Ecumenical Review (quarterly); Ecumenical News International (weekly); International Review of Mission (quarterly).

\section{Further Reading}

Castro, E., A Passion for Unity. Geneva, 1992

Raiser, K., Ecumenism in Transition. Geneva, 1994

Van Elderen, M. and Conway, M., Introducing the World Council of Churches revised and enlarged edition. Geneva, 1991

\section{World Customs Organization}

Established in 1952 as the Customs Co-operation Council, the World Customs Organization is an intergovernmental body with 